\title{
SOME HEMATOLOGICAL AND BIOCHEMICAL CHANGES IN TILAPIA, Oreochromis niloticus And Tilapia zillii EXPOSED TO MIXTURE OF COPPER AND LEAD.
}

\author{
*Abdel-Salam M.I. Ohaida, **Noha Mahmood A. Akrawee and \\ ***Dayhoum A.Al-Bassel \\ * Biology Department, Faculty of Science, 7 October University, Misurata, Libya \\ ** Higher Institute of Medical Technology, Misurata, Lybia \\ *** Zoology Department, Faculty of Science, Fayoum University
}

\section{ABSTRACT}

A hematological and biochemical study was coducted on the freshwater fish Oreochromis niloticus and Tilapia zillii. The fish were acclimated to laboratory conditions for two weeks before use. Then the fish were exposed for 12 weeks to a mixture of copper and lead at a ratio 1:1 of the $\mathrm{LC}_{50}$ of both metals. Hematological and biochemical analyses were carried out every two weeks during the exposure period. Results indicted the following:

In the hematological study, there was a significant increase in the total erythrocytes count (RBCs), as well as the hematocrite (Ht) and mean corpuscular hemoglobin concentration (MCHC) in O. niloticus upon exposure to the heavy metals mixture .This increase was observed after 10 weeks for RBCs count, from the $6^{\text {th }}$ week of exposure till the end of the experiment for $\mathrm{Ht}$ and throughout the whole time of exposure for MCHC. For T. zillii, the increase in the RBCs count was noticed at weeks 4,6 and 12; the increase in Ht occurred at weeks 10 and 12; while a decrease in $\mathrm{MCHC}$ was noticed during the entire period of exposure. On the other hand, hemoglobin content $(\mathrm{Hb})$ decreased significantly starting from the second week of exposure till the end of the experiment for O. niloticus. Similar decrease was noticed for $T$. zillii (except the value at 8 weeks of exposure) and continued till the end of the exposure period.

Non significant changes were observed in the serum glucose concentration for O.niloticus, while serum glucose was significantly increased in metals treated $T$. zillii. For both species, non significant changes were noticed in Liver and muscle's glycogen levels. However, serum protein levels were significantly increased in $O$. niloticus, but changes were non significant in T. zillii. On the other hand, muscle total protein showed a significant decrease after 10 weeks of exposure in O. niloticus. Such significant decrease in muscle total protein of $T$. zillii appeared only during the $12^{\text {th }}$ week of exposure. Changes in serum creatinine and uric acid levels in $O$. niloticus starting from the $8^{\text {th }}$ week of exposure till the end of the experiment.

Key words: Tilapia - Copper - Lead - Blood - Muscles - Liver .

\section{INTRODUCTION}

In recent years, heavy metals are widely distributed in aquatic systems due to industrial development and the wide use of chemicals in agriculture as well as

Fayoum J. Agric. Res. \& Dev., Vol.22, No.1, January, 2008 
Abdel-Salam M.I. Ohaida, et al.,

the lack of environmental regulations (El-Nabawi, et al., 1987; Calamari and Nave, 1994; Abdelhamid and El-Zareef, 1996; Zaghloul, 1997 and Abdelhamid and Gawish, 1998). The passage of different environmental pollutants to the aquatic system demonstrates the need for a comprehensive study for their effects on the living resources. Waste discharges never occur singly but always as a mixture (Abdelhamid $\boldsymbol{e t}$ al., 1997; 2000 and 2006 a). A knowledge of mixture toxicity is important in determining water quality criteria since interaction may increase or decrease toxicity depending upon the nature of the individual pollutants (Sprague and Fogles, 1977).

Copper and lead are considered as the most toxic among heavy metals, which are detectable practically in aquatic environment and in all biological systems (Haux and Larsson, 1982 and Ghazaly and Said, 1995).

Copper and lead toxicity depends on many factors such as species differences, life stage, concentration in food and water, food consumption rate, water quality, time of exposure and metal speciation in water (Elsa, 1991and Ghazaly and Said, 1995).

Hematological and biochemical measurements have been used as good indicators of the state of fish health condition in addition to the detection and diagnosis of metabolic processes (Heath, 1987).

The toxicity of heavy metals to different fish species have been reported by many authors (Radhakrishanalah et al., 1992; Ghazaly and Said, 1995; James and Sanpath, 1995; El-Sabbagh, 1996 and Rizkalla et al., 1999). However, information about the subchronic toxicity of copper and lead mixture are not currently available.

The aim of the present study was to examine and evaluate the magnitude of hematological and biochemical alterations in blue tilapia O. niloticus and Tilapia zillii after exposure to chronic concentration of copper and lead mixture in a concentration of $1: 1$ of $\mathrm{LC}_{50}$ copper and lead for 12 weeks.

\section{MATERIALS AND METHODS}

\section{Sample collection and treatment manipulation:}

Specimens of the tilapia, Oreochromis niloticus and Tilapia zillii 36.38 $\pm 0.77 \mathrm{~g}$ in weight and $12.93 \pm 0.88 \mathrm{~cm}$ in length were caught from Tawarga pond and transported immediately to the fish laboratory at Biology Department, Faculty of Science, 7 October University. The experimental fishes were reared in aerated glass aquaria $(75 \times 50 \times 50 \mathrm{~cm})$, each of about $187 \mathrm{~L}$ capacity and acclimatized for two weeks before being used in the experimental study. The studied fishes were fed $25 \% \mathrm{CP}$ commercial fish diet at a ratio of $3 \%$ of their body weight /day. During this acclimation period the mortality was less than $2 \%$. Fishes were not fed for 48 hours prior to the experiments. Water temperature, $\mathrm{pH}$, dissolved oxygen, copper and lead (for the control group) concentrations were $26.07 \pm 1.17$ ${ }^{\circ} \mathrm{C}$ (measured three times daily), $6.81 \pm 0.05$ (measured daily), 6.02 $\pm 0.02 \mathrm{ppm}$ (measured daily) and $0.00 \mathrm{ppm}$ (Measured weekly) respectively.

At the end of the acclimation period individuals of $O$. niloticus and T.zillii were divided randomly into six experimental groups (20 fish each) and reared separately in aquaria containing copper and lead mixture. The aquaria were provided with air pumps for aeration during the entire exposure period. Another

Fayoum J. Agric. Res. \& Dev., Vol.22, No.1, January, 2008 
SOME HEMATOLOGICAL AND BIOCHEMICAL CHANGES IN...... 96 group (from each fish species) was kept in an aerated aquarium containing natural water and used as a control.

Stock solutions (1000 ppm) of copper as copper sulphate $\left\{\mathrm{Cu} \mathrm{SO}_{4} .5 \mathrm{H}_{2} \mathrm{O}\right\}$ Analar (Merk) and of lead as lead nitrate $\left\{\mathrm{Pb}\left(\mathrm{NO}_{3}\right)_{2}\right\}$ Analar (Merk) were prepared separately and used in preparing the experimental water (to which fish were exposed) containing the mixture of the two metals at a ratio 1:1 of the 96 hours $\mathrm{LC}_{50}$ values of copper and lead $\left(\mathrm{LC}_{50}\right.$ is the concentration of toxicant causing $50 \%$ mortality). The $96 \mathrm{hr} \mathrm{LC}_{50}$ values in both fish species previously determined according to the method described by Litchfield and Wilcoxon (1949). These values were: 8.15 and $25.88 \mathrm{ppm}$ copper and lead, respectively for $O$. niloticus, while they were 6.95 and $17.44 \mathrm{ppm}$ copper and lead, respectively for T. zillii.

For each fish species, five individuals from the treated groups (and five control fishes) were taken after 2,4, 6, 8, 10 and 12 weeks of exposure to the metals mixture. Blood and tissue samples were obtained for hematological and biochemical analysis.

\section{Blood sampling:}

Blood samples were withdrawn from the arteria caudalis. The needle (heparinized glass pipette) was run quite deep through the middle line just behind the anal fin in a dorso-cranial direction.

Serum was obtained by centrifugation (at $5000 \mathrm{rpm}$ for 12 minutes) and was stored at -20 degrees centigrade for further analysis.

Muscle and Liver sampling:

After decapitation of fish, pieces of white apaxial muscle and liver were taken. The muscle and liver samples were transferred directly into weighing jars and accurately weighed. Then, the jars were placed in a drying oven which is thermostatically controlled at 105 degrees centigrade for 72 hours.

\section{Hematological analysis:}

Erythrocytes (RBCs) and leukocytes (WBCs) count was carried out using the improved Neubauer Hematocytometer (Maxine and Benjamine, 1985). Hemoglobin content $(\mathrm{Hb})$ was measured as descried by Zulsira (1961). The Hematocrite volume (PCV), mean corpuscular volume (MCV), mean corpuscular hemoglobin $(\mathrm{MCH})$ and mean corpuscular hemoglobin concentration (MCHC) were calculated as described by Maxine and Benjamine (1985).

\section{Biochemical analysis:}

Commercial diagnostic kits from Bio-Merieux chemicals (France) were used for the following biochemical assays.

The concentration of serum glucose was measured by the GOD-PAD method (Enzymatic Colorimetric method) according to Trinder (1969). Total protein levels were determined by biurret test according to Henry (1964). Serum creatinine was measured colorimetrically as described by Henry (1974). Serum uric acid was determined according to Barham and Trinder (1972).

Tissue analysis:

Liver and muscle glycogen levels were determined using the anthrone reagent according to the method of Handle and Van (1965). Muscle total protein was estimated as mentioned by Josylne (1950).

Fayoum J. Agric. Res. \& Dev., Vol.22, No.1, January, 2008 


\section{Statistical analysis:}

The results were statistically analyzed using the analysis of variance (ANOVA) and Duncan's multiple comparison test to compare between means at $\mathrm{P}<0.05$ (Steel and Torrrie, 1980).

\section{RESULTS}

\section{Hematological analysis:}

The results of hematological studies on Oreochromis niloticus are illustrated in Table (1). The exposure of fish to $1: 1$ of the $\mathrm{LC}_{50}$ of copper and lead showed a gradual non significant increase in the total RBCs count. After 10 weeks of exposure, a significant increase was noticed $(\mathrm{P}<0.05)$. However, significant decrease $(\mathrm{P}<0.01)$ in the total $\mathrm{RBC}$ count of Tilapia zillii was noticed during the $10^{\text {th }}$ week of exposure, while an increase was noticed at weeks 4,6 and 12 . Non significant change $(\mathrm{P}>0.05)$ in the total WBCs count was recorded in both species.

Hemoglobin content was decreased significantly $(\mathrm{P}<0.01)$ starting from the second week of exposure till the end of the experiment for Oreochromis niloticus. Similar decrease $(\mathrm{P}<0.01)$ was noticed in Tilapia zillii during the entire exposure period (except the value at eight weeks of exposure).

Table (1): Changes of blood pictures in Oreochromis niloticus and Tilapia zillii exposed to 1:1 of $\mathrm{LC}_{50}$ of copper and lead mixture for 12 weeks (w).

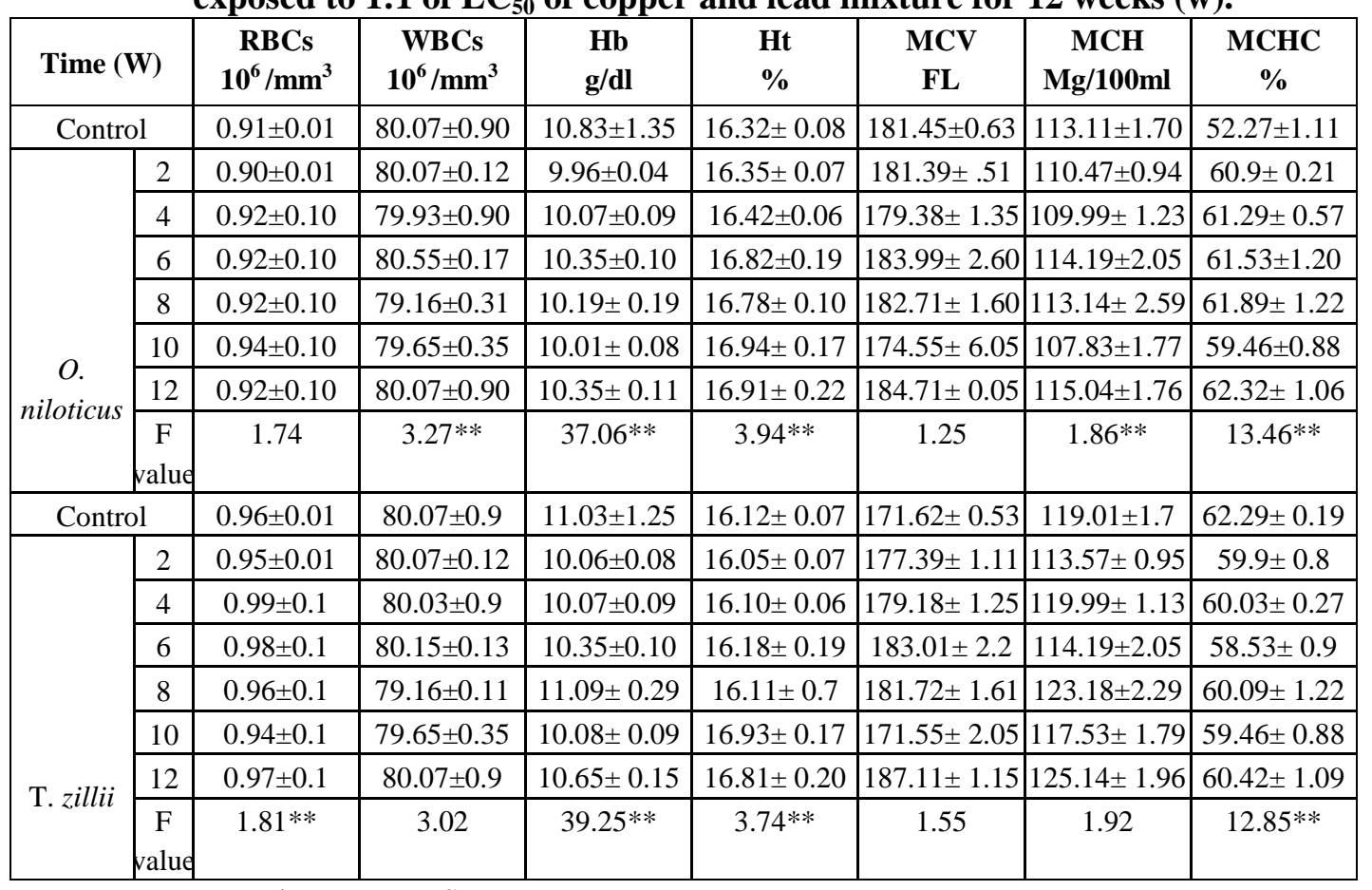

Data are represented as means \pm S.E.

Fayoum J. Agric. Res. \& Dev., Vol.22, No.1, January, 2008 
SOME HEMATOLOGICAL AND BIOCHEMICAL CHANGES IN...... 98

The hematocrit value of, Oreochromis niloticus was significantly increased $(\mathrm{P}<0.01)$ at week six eight and tweelve of exposure. Such increase was not noticed in case of Tilapia zillii till the $10^{\text {th }}$ week of exposure.

Red cell indices of exposed fishes revealed non-significant changes $(\mathrm{P}>0.05)$ in $\mathrm{MCV}$ values from the control mean value for Oreochromis niloticus throughout the entire experimental period. The MCV value of Tilapia zillii also showed a non-significant change till the $12^{\text {th }}$ week of the exposure. A significant decrease $(\mathrm{P}<0.05)$ in $\mathrm{MCH}$ values was recorded in Oreochromis niloticus after 10 weeks of exposure. While a non-significant change $(\mathrm{P}>0.05)$ was noticed for Tilapia zillii during the entire period of exposure. However, a significant increase was noticed in MCHC value $(\mathrm{P}<0.05)$ during the entire exposure period for Oreochromis niloticus. The MCHC for Tilapia zillii showed a decrease which was significant $(\mathrm{P}<0.05)$ only at the $10^{\text {th }}$ week of exposure.

\section{Biochemical analysis:}

As shown in Table 2, serum glucose, concentrations for Oreochromis niloticus showed non-significant changes (P> 0.05) throughout the whole period of exposure compared with the control fish. On the other hand, a significant increase $(\mathrm{P}<0.05)$ was noticed in serum glucose of Tilapia zillii upon exposure to the metals. Liver and muscle glycogen concentrations for in both fish species showed non-significant changes $(\mathrm{P}>0.05)$ throughout the whole period of exposure compared with control fish.

Table (2): Changes of serum glucose $(\mathrm{mg} / \mathrm{dl})$,liver glycogen $(\mathrm{mg} / \mathrm{g}$ fresh weight) and muscle glycogen $(\mathrm{mg} / \mathrm{g}$ fresh weight) in Oreochromis niloticus and Tilapia zillii exposed to 1:1 of $\mathrm{LC}_{50}$ of copper and lead mixture for 12 weeks $(w)$.

\begin{tabular}{|c|c|c|c|c|c|c|}
\hline \multirow{2}{*}{$\begin{array}{r}\text { Time } \\
\text { (w) }\end{array}$} & \multicolumn{2}{|c|}{ Serum Glucose } & \multicolumn{2}{|c|}{ Liver Glycogen } & \multicolumn{2}{|c|}{ Muscle Glycogen } \\
\hline & O. niloticus & T. zillii & O. niloticus & T. zillii & O. niloticus & T. zillii \\
\hline Control & $64.83 \pm 1.30$ & $62.93 \pm 1.49$ & $20.6 \pm 0.41$ & $19.14 \pm 0.21$ & $2.34 \pm 0.02$ & $2.28 \pm 0.02$ \\
\hline 2 & $62.50 \pm 0.97$ & $63.58 \pm 1.97$ & $20.48 \pm 0.46$ & $19.46 \pm 0.36$ & $2.23 \pm 0.01$ & $2.28 \pm 0.01$ \\
\hline 4 & $62.71 \pm 1.34$ & $66.11 \pm 1.74$ & $20.47 \pm 0.44$ & $19.27 \pm 0.34$ & $2.23 \pm 0.01$ & $2.28 \pm 0.01$ \\
\hline 6 & $61.11 \pm 0.80$ & $68.11 \pm 7.18$ & $20.43 \pm 0.37$ & $19.32 \pm 0.31$ & $2.24 \pm 0.01$ & $2.27 \pm 0.01$ \\
\hline 8 & $62.73 \pm 1.57$ & $69.13 \pm 2.07$ & $20.32 \pm 0.32$ & $19.29 \pm 0.36$ & $2.24 \pm 0.01$ & $2.27 \pm 0.01$ \\
\hline 10 & $62.33 \pm 1.09$ & $66.39 \pm 1.12$ & $20.40 \pm 0.32$ & $\mathbf{1 9 . 2 4} \pm 0.42$ & $2.24 \pm 0.01$ & $2.26 \pm 0.01$ \\
\hline 12 & $62.23 \pm 0.93$ & $68.21 \pm 1.23$ & $20.34 \pm 0.31$ & $19.54 \pm 0.39$ & $2.23 \pm 0.01$ & $2.26 \pm 0.01$ \\
\hline F value & 1.94 & $2.24 * *$ & 0.05 & 0.01 & 0.12 & 1.02 \\
\hline
\end{tabular}

Data are represented as means \pm S.E.

Serum total protein showed a non-significant difference $(\mathrm{P}>0.05)$ throughout the whole period of exposure in Tilapia zilli.But there was a significant increase $(\mathrm{P}<0.05)$ in serum total protein for Oreochromis niloticus after ten weeks of exposure to copper and lead mixture (Table 3). The muscular total protein values of Oreochromis niloticus showed a significant decrease $(\mathrm{P}<0.05)$ only after 10 weeks of exposure till the end of the study period. Meanwhile Tilapia zillii showed a non-significant decrease $(\mathrm{P}>0.05)$ in muscular

Fayoum J. Agric. Res. \& Dev., Vol.22, No.1, January, 2008 
Abdel-Salam M.I. Ohaida, et al.,

total protein during the first 10 weeks of exposure while a significant decrease was noticed at 12 weeks of exposure.

As shown in Table (4), the level of serum creatinine in both Oreochromis niloticus and Tilapia zillii exposed to copper and lead mixture showed nonsignificant changes compared with values of the control fish. Values of uric acid in bothspecies showed non-significant changes $(\mathrm{P}>0.05)$ during the first 8 weeks of exposure, while they increased significantly $(\mathrm{P}<0.05)$ at weeks 10 and 12.

Table (3): Changes of serum total protein (g/dl) in Oreochromis niloticus and Tilapia zillii exposed to 1:1 of $\mathrm{LC}_{50}$ of copper and lead mixture for12 weeks (w).

\begin{tabular}{|c|c|c|c|c|}
\hline \multirow{2}{*}{$\begin{array}{c}\text { Time } \\
(\mathbf{w})\end{array}$} & \multicolumn{2}{|c|}{ Serum total protein } & \multicolumn{2}{c|}{ Muscle total protein } \\
\cline { 2 - 5 } & $\boldsymbol{O}$. niloticus & $\boldsymbol{T}$. zillii & O. niloticus & $\boldsymbol{T}$. zillii \\
\hline Control & $5.84 \pm 0.21$ & $6.06 \pm 0.19$ & $16.79 \pm 0.07$ & $14.62 \pm 1.11$ \\
\hline 2 & $6.23 \pm 0.10$ & $5.69 \pm 0.22$ & $16.78 \pm 0.06$ & $14.59 \pm 0.09$ \\
\hline 4 & $6.33 \pm 0.10$ & $5.63 \pm 0.20$ & $16.81 \pm 0.04$ & $14.51 \pm 0.07$ \\
\hline 6 & $6.35 \pm 0.10$ & $5.56 \pm 0.18$ & $16.72 \pm 0.05$ & $14.51 \pm 0.05$ \\
\hline 8 & $6.35 \pm 0.10$ & $5.49 \pm 0.19$ & $16.73 \pm 0.05$ & $14.66 \pm 0.06$ \\
\hline 10 & $6.39 \pm 0.07$ & $5.41 \pm 0.19$ & $16.60 \pm 0.06$ & $14.46 \pm 0.08$ \\
\hline 12 & $6.50 \pm 0.07$ & $5.34 \pm 0.18$ & $16.41 \pm 0.02$ & $14.28 \pm 0.04$ \\
\hline F value & $1.25 * *$ & 1.52 & $7.4 * *$ & $3.14 * *$ \\
\hline
\end{tabular}

Data are represented as means \pm S.E.

Table (4): Changes of serum creatinine ( $\mathrm{mg} / \mathrm{dl})$ and serum uric acid (mg/dl) in Oreochromis niloticus and Tilapia zillii exposed to 1:1 of $\mathrm{LC}_{50}$ of copper and lead mixture for 12 weeks $(w)$.

\begin{tabular}{|c|c|c|c|c|}
\hline \multirow{2}{*}{$\begin{array}{c}\text { Time } \\
(\mathbf{w})\end{array}$} & \multicolumn{2}{|c|}{ Serum creatinine } & \multicolumn{2}{c|}{ Serum uric acid } \\
\cline { 2 - 5 } & O. niloticus & $\boldsymbol{T}$. zillii & O. niloticus & $\boldsymbol{T}$. zillii \\
\hline Control & $1.01 \pm 0.05$ & $0.97 \pm 0.05$ & $14.4 \pm 0.24$ & $15.96 \pm 0.36$ \\
\hline 2 & $0.91 \pm 0.03$ & $0.97 \pm 0.05$ & $14.21 \pm 0.23$ & $15.53 \pm 0.29$ \\
\hline 4 & $0.91 \pm 0.03$ & $0.97 \pm 0.05$ & $14.45 \pm 0.21$ & $15.75 \pm 0.29$ \\
\hline 6 & $0.92 \pm 0.03$ & $0.95 \pm 0.05$ & $14.70 \pm 0.19$ & $16.06 \pm 0.31$ \\
\hline 8 & $0.93 \pm 0.04$ & $0.94 \pm 0.05$ & $15.09 \pm 0.22$ & $16.31 \pm 0.27$ \\
\hline 10 & $0.93 \pm 0.04$ & $0.98 \pm 0.04$ & $15.26 \pm 0.23$ & $16.63 \pm 0.25$ \\
\hline 12 & $0.94 \pm 0.04$ & $0.99 \pm 0.03$ & $15.51 \pm 0.28$ & $16.85 \pm 0.25$ \\
\hline F value & 0.82 & 0.12 & $4.54^{* *}$ & $2.63^{* *}$ \\
\hline
\end{tabular}

Data are represented as means \pm S.E.

\section{DISCUSSION}

Many hematological, biochemical and physiological variables show specific responses to certain types of environmental stressors such as heavy metals (Abu-El Ella, 1996 and Rizkalla et al., 1999). This feature, of such responses, makes them particularly useful in fisheries management and resources protection as a mean of identifying possible courses of environmental

Fayoum J. Agric. Res. \& Dev., Vol.22, No.1, January, 2008 
SOME HEMATOLOGICAL AND BIOCHEMICAL CHANGES IN...... 100 deterioration. However, the possibility to standard as diagnostic tool is still not definitive.

The present investigation dealt with hematological changes induced in Oreochromis niloticus and Tilapia zillii when both species were exposed individually to $1: 1$ of the $\mathrm{LC}_{50}$ of copper and lead for 12 weeks.

In the hematological study, there was a significant increase in the total RBC's count, the Ht and MCHC in Oreochromis niloticus during the $10^{\text {th }}$ week of exposure for RBCs, from the $6^{\text {th }}$ week of exposure till the end of the experiment for $\mathrm{Ht}$ and throughout the whole time of exposure for MCHC. While such increase in the RBCs count, $\mathrm{Ht}$ and MCHC values was noticed in case of Tilapia zillii at the $12^{\text {th }}$ week of exposure.

Increase in RBCs count and $\mathrm{Ht}$ value of the two studied species may be attributed to impairment of gas exchange by the gills and a release of erythrocytes from the spleen to compensate impaired oxygen uptake, which resulted from disturbed gill function (Larsson et al., 1980). It may also reflect hypoxic stress resulting in secondary polycythemia and/or a decrease in rate of erythrocyte destruction as previously reported by Salah El- Deen $\boldsymbol{e t}$ al., 1997. The increase in MCHC was also previously observed by Ahmed et al., 1992 for Oreochromis niloticus that affected by ammonia.

On the other hand, $\mathrm{Hb}$ decreased significantly starting from the second week of exposure till the end of the experiment for Oreochromis niloticus. Such decrease was noticed for Tilapia zillii after 10 weeks of exposure. Similar results was obtained by Mukherjee and Sinha (1993) who found that exposure to 20 $\mathrm{mg} / \mathrm{L}$ of $\mathrm{CdCl}$ for 2 weeks caused a significant decrease in hemoglobin of Labeo rohita. Rizkalla et al., 1999 also found such $\mathrm{Hb}$ decrease in Tilapia zillii exposed to a combination of copper and zinc for 30 and 90 days respectively. Such reduction in $\mathrm{Hb}$ level could be attributed to the intrahepatic and intraspleenic hemorrhage (Sinovcic et al., 1980).

Higher concentration of heavy metals beyond the tolerance limit may cause fluctuation in some blood parameters such as MCV, MCH and MCHC. These changes may include disturbances in the production of erythrocytes from haemopoitic tissue and changes in their volume (Marie, 1990 and 1992).

In the present study. MCV and MCH values of the exposed Oreochromis niloticus showed non-significant changes form the control mean value throughout the entire experimental period(except $\mathrm{MCH}$ value at weeks 10and 12), while a significant increase in the values of those parameters in Tilapia zillii was recorded at 12 weeks of exposure. The increased MCV and MCH in Tilapia zillii could be attributed to hemolytic action of lead, which led to fluid loss from the tissues with subsequent decrease in plasma volume. This assumption is highly supported by Swift (1981).

It is assumed from the present results that the increase of the blood indices $\mathrm{MCV}, \mathrm{MCH}$ and $\mathrm{MCHC}$ may be attributed to a defense reaction against the toxicity of heavy metal through stimulation of erythropesis. This is similarly observed by Rizkalla $\boldsymbol{e t}$ al., (1999) and supported by the opinion of Abd-Alla $\boldsymbol{e t}$ al. (1992).

In biochemical studies, blood glucose measurements are known to be a sensitive indicator for environmental stress in fish. In the present study, serum

Fayoum J. Agric. Res. \& Dev., Vol.22, No.1, January, 2008 
Abdel-Salam M.I. Ohaida, et al.,

glucose as well as liver and muscle glycogen concentration of the two fish species showed non-significant changes when both species were exposed individually to $1: 1$ of the $\mathrm{LC}_{50}$ of copper and lead mixture throughout the whole period of exposure. Such non-significant changes could be explained by the antagonistic effect of copper and lead on the gluconeogenesis process. Several authors (Radhakrishanalah $\boldsymbol{e t}$ al., 1992 and Ghazaly and Said, 1995) reported a direct correlation between copper treatment and substantial loss of liver and an increase in the activities of liver glycogen phosphorylase and glucose-6-phosphatase. They added that muscle glycogen was also decreased along with an increase in its glycogen phosphorylase activity accompanied by a considerable rise in the plasma glucose level. Such hyperglycemic effect was attributed to the increased secretion of catecholamines from adrenal medulla. Gluth and Hanke (1984) concluded that the reduction of the amount of liver and muscle glycogen is also a good indicator of toxicity.

The hyperglycemic effect of copper treatment was antagonized by the inhibitory effect of lead on the gluconeogenes process suggested by Corell (1974). Similarly, several authors have also noticed the inhibitory effect of lead on serum glucose level in different fish species (Salmeron et al., 1990 for blue tilapia (Oreochromis aureus) and Haux and Larsson, 1982 for Rainbow trout Salmo gairdneri). This antagonistic effect of copper and lead on the glucoeogenesis process may partially explain the immobilization of liver glycogen into blood glucose.

An important function of serum protein is the maintenance of osmotic balance between the circulating blood and the cell membrane (Harper et al., 1977). In the present study, serum total protein of Oreochromis niloticus showed a pronounced significant increase throughout the whole period of exposure reaching its maximum value during the $12^{\text {th }}$ week. This significant increase in total protein was only noticed in Tilapia zillii after 8 weeks of exposure.

The increased serum protein in both $O$. niloticus and $T$. zillii exposed to sublethal concentrations of copper and lead mixture in the present study could be attributed to several pathological conditions such as damage of liver, kidneys and gills. This could be due to accumulation of metals in these organs and relative changes in the mobilization of serum protein (Reichert et al., 1979). The increase in serum total protein in fishes exposed to metals may also be due to impaired water balance (Harper et al., 1977).

In general, the changes in plasma total protein would seem to be of a great value for the additional expenditure of energy but of a limited value as potential specific indicators in fish exposed to pollutants. This conclusion was in agreement with the findings reported by Alam and Mahughan (1992).

Regarding the effect of exposure to copper and lead mixture on meat quality of the two studied species in the present work, it has been observed a decrease in the muscle total protein. Such decrease was noticed for $O$. niloticus and $T$. zillii after 10 and 12 weeks of exposure, respectively. The decrease in muscle total protein could be attributed to the reduction in food consumption and/or decrease in gross food conversion. It could be also related to the decrease in insulin level detected by the observed higher serum glucose level in copper and

Fayoum J. Agric. Res. \& Dev., Vol.22, No.1, January, 2008 
SOME HEMATOLOGICAL AND BIOCHEMICAL CHANGES IN...... 102 lead exposed fish. Insulin has greater effect on protogenic and lipogenic pathways (Zaghloul, 1997).

Increasing levels of creatinine and uric acid above normal values indicate several disturbances in kidney function (Maxine and Benjamine, 1985). A significant increase in the uric acid level was noticed for O. niloticus starting from the $10^{\text {th }}$ week of exposure till the end of the experiment. On the other hand, nonsignificant changes in the level of serum creatinine and uric acid were noticed in Tilapia zillii during the period of the experiment. Such increase in the uric acid level was noticed by other investigators (Zaghloul, 1997).

Recently, Abdelhamid et al. (2006 b) found that copper led to higher WBC's but lower RBC's, $\mathrm{Ht}, \mathrm{Hb}$, glucose and total protein of Nile tilapia plasma.

It could be concluded, that the combination of copper and lead induced different hematological and biochemical alterations which in turn may affect fish production and its meat quality. This may indicate the importance of further studies on the mode of action of different heavy metals both individually and as mixtures.

\section{REFERENCES}

Abd- Alla, G.A., Ibrahim, M.S., Bahnasawy, M.H. And Abdel- Baki, T.E. (1992): Toxic effects of some water pollutants (gallant and mercury) on blood parameters of catfish (Clarias lazera) J. Egypt. Ger. Soc. Zool., 6 (A): 202-209.

Abdelhamid, A.M. and A.A.M. El-Zareef (1996): Further studies of the pollution status on the southern region of El-Manzalah Lake. Proceeding of the $6^{\text {th }}$ International Conference on Environmental Protection is a Must, 21-23 May, Sheraton Alexandria. pp: 65-76. [Food Borne Contamination and Egyptian's Health Conference, 26-27 Nov., 1966, pp: 141-150].

Abdelhamid, A.M. and M.M. Gawish (1998): Studies on some trace metal contents of shrimp and crab from Mediterranian shore of Damietta Governorate. Egypt. J. Aquat. Biol. \& Fish., 2(4) : 47-64.

Abdelhamid, A.M., A.A. El-Kerdawy, A.A.M. El-Mezaein and H. A. Meshref (1997): Study on pollution in the western-north region of El-Manzalah Lake, Egypt. II. Heavy metals [Iron, zinc, lead and cadmium] in water, soil and fish. J. Agric. Sci. Mansoura Univ., 22: 1877-1885.

Abdelhamid, A.M., A.A. Abdelghaffar and A.A. El-Kerdawy (2000): Towards causative interpretation of the repeatedly sudden and collective death of fish in Damietta region. J. Agric. Sci. Mansoura Univ., 25: 1947-1962.

Abdelhamid, A.M., M.M. Gawish and A.A. Soryal (2006 a): Comparative study between desert cultivated and natural fisheries of mullet fish in Egypt: I.Concerning heavy metals. J. Agric. Sci. Mansoura Univ., 31(9): 5665-5680.

Abdelhamid, A.M., B.R. Nemetallah, M.A. Abd Allah and T.A.E. Mousa (2006 b): Hemolytic activity in blood serum of Oreochromis niloticus under different types of stress. Thr $3^{\text {rd }}$ Int. Conf. for Develop. And the Env. In the Arab - World, March 21-23, Assiut, pp: 153-169.

Fayoum J. Agric. Res. \& Dev., Vol.22, No.1, January, 2008 
Abdel-Salam M.I. Ohaida, et al.,

Abu El-Ella, S.M. (1996): Studies on the toxicity and bioconcentration of cadmium on grass carp Ctenopharyngodon idela, M.Sc. Thesis, Faculty of Science, Helwan University, Egypt.

Ahmed, N.A., El-Serafy, S.S., El- Shafey, A.M. and Abd El-Hamid, A.H. (1992): Effect of ammonia on some haematolgical parameters of Orechromis niloticus. Proc. Zool. Soc. A. R. Egypt, 23 (1): 155-160.

Alam, M.K. and Mahughan, O. E. (1992): The effect of malathion and various concentrations of zinc, copper, nickel, lead and mercury on fish. Biological Trace Element Research Journal, 34 (3): 225-238.

Barham, D. and Trinder, P. (1972): Enzymatic determination of uric acid, Analysis, 97: 142-145.

Federation (1985): Standards methods for the examination of water and . wastewater. $16^{\text {th }}$ ed. American Public Health Association, New York, NY.

Barham, D. and Trinder, P. (1972): Enzymatic determination of uric acid. Analysis, 97: 142-145.

Calamari, D. and Nave, H. (1994): Review of pollution in the African aquatic environment. CIFA Technical PP . No.25 Rome, FAO. 118p.

Cornell, R. (1974): Depression of hepatic gluconegenesis by acute lead boisoning in rats, Physiologist, 17:199. Fishes and pink shrimp. Bull. Environ. Contam. Toxicol., 11: 384-392.

Dange, A. D. (1986): Changes in carbohydrate metaboslism in tilapia, exposed to diferent types of pollutants, Environ. Pollut., A-Ecol. Biol., 41(2): 165177.

El-Nabawi, A., Heinzow, B. and Kruse, $\mathrm{H}$. (1987): $\mathrm{As}, \mathrm{Cd}, \mathrm{Cu}, \mathrm{Pb}, \mathrm{Hg}$ and $\mathrm{Zn}$ in fish from the Alexandria region .Egypt. Bull. Environ. Contam. Toxicol., 39: 889-897.

Elsa, M.B.S. (1991): Metal poisning in fish, environmental and life. Sciences Associates Austin, Texas 78720. CRC Press Inc.,Boston.

El-Sabbagh, H.S. (1996): Biochemical and hematological changes in Tilapia nilotica (Oreohromis niolticus) exposed to copper. Vet. Med .J., Giza, 44 (1): 23-30.

Ghazaly, K.S. and Said, K.M. (1995): Physiological characteristic of Tilpia nilotica under acute stress of copper. J. Egypt. Ger. Soc. Zool., Comparative Physiology, 16 (A): 287-301.

Gluth, G. and HankeE, W. (1984): A comparison of physiological changes in carp, Cyprinus carpio, induced by several pollutants at sublethal concentrations. Comp. Biochem. Physiol., 79C: 39-51.

Handle, P. and Van, I. (1965): Estimation of glycogen in small amount of tissue. Anal. Bioch. 11: 256-265.

Harper, H.A., Roodwell, V.W. and Mayes, P.A. (1977): Review of Physiological Chemistry, Lang Medical Publications, Los Anglos, CA.

Haux, C. and Larsson, A. (1982): Influence of inorganic lead on the biochemical blood composition in the rainbow trout (Salmo gairneri). Ecotoxicol. and Environ. Saf., 6: 28-34.

Heath, A.C. (1987): Water pollution and fish physiology. CRC Press Inc. Boca Raton, Florida.

Fayoum J. Agric. Res. \& Dev., Vol.22, No.1, January, 2008 
SOME HEMATOLOGICAL AND BIOCHEMICAL CHANGES IN......

Henry, R.J. (1964): Clinical Chemistry, Harper and Row publishers, New York,pp. 181.

Henry, R.J. (1974): Clinical Chemistry,Principles and Techniques, $2^{\text {nd }}$ Edition; Harper and Row publishers, New York, PP.525.

James, R. and Sanbath, K, (1995): Sublethal effects of mixtures of copper and ammonia on selected biochemical and physiological parameters in the catfish, Heteropneustas fossilis (Bloch). Bull. Environ. Contam. Toxicol., 55: $187-194$.

Joslyne, M.A. (1950): Methods in food analysis Chapter 20, Academic Press, New York.

Larsson, A., Lehtinem, K.J. and Haux, C. (1980): Biochemical and Hematological effects of titanium dioxide industrial effluent on fish, Bull. Environ. Contam. Toxicol., 25: 427-433.

Litchfield, J.T. and Wilcoxon, F. (1949): A simplified method of evaluating dose effect experiments. J. Pharmacol. Exper. Therap., 96: 99-114.

Marie, M.A.S. (1990): Effect of sublethal concentration of zine on blood parameters of the Nile catfish, Clarias lazera. J. Bros .Zool. Soc. A.R. Egypt, 18; 413-423.

Marie, M.A.S. (1992): Influence of low and high $\mathrm{pH}$ on blood parameters and plasma electrolytes of common carp: Cyprinus carpio, J. Egypt. Ger. Soc. Zool., 9 (A): [ Comp. Physiol.]. 175-189.

Maxine, M. and Benjamine, B. S. (1985): Outline of Veterinary Clinical Pathology, $3^{\text {rd }}$ edition; Colorado State University.

Mukherjee, J.R. and Sinha, G.M. (1993): Cadmium toxicity on haematological and biochemical aspects in an Indian freshwater Biol., 5(3):245-251.

Radhakrishanalah, K., Venkatavamana, B., Suresh, A. and Sivaramakrihna, B. (1992): Effects of lethal and sublethal concentrations of copper on glycolysis in liver and muscle of the fresh water teleost Labeo rohita (Hamilton). J. Environ. Biol., 13(1): 63-68.

Reichert, W.L., Flderighi, D.A. and Malins, D.C. (1979): Uptake and metabolism of lead and cadmium in Coho salmon (Oncorhynchus kisutch), Comp. Biochem. Physiol., 63c: 229-235

Rizkalla, E.H., Abd El-Haleem, M.E. and Shalaby, A.M.E. (1999): Hematological changes in Cyprinus caprio as a result of short and long term exposure to different combinations of copper, cadmium and zinc. Egypt. J. Aquat. Biol. \& Fish., 3 (1): 175-193.

Salah El-Deen, M.A., Khattab, A.F. and Abu El-Ella, S.M. (1997): Toxicological effects of cadmium on some physiological characteristics of grass carp; Ctenobharyngodon idella. Egypt. J. Zool., 29: 169-184.

Salmeron, F.P., Melendez, C.M. E. and Martiez, T.L. (1990): Hepatotoxic and nephrotoxic effects of lead on the tilapia Sarotherodon aureus.J. Anales de la Escuela Nacional de Ciencias Biologicas, Mexico, 33(1-4): 147-158.

Sinovcic, G., Gutierrez, M. and Establier, R. (1980): On the accumulation of mercury in the blood, liver, spleen and kidney of Halobatrachus dtdactylus Schneider, and resulting hematological, cytohematologic and histopathologic alterations. Acta.Adinot., 21: 219- 225.

Fayoum J. Agric. Res. \& Dev., Vol.22, No.1, January, 2008 
Abdel-Salam M.I. Ohaida, et al.,

Steel, R. G. D. and Torrie, J. H. (1980): Principles and Proceedures of Statistics, a Bioenergetics Approach. McGraw-Hill Book Co., New York.

Swift, D.J. (1981): A holding box system for physiological experiments on rainbow trout, Salmo gairdneri (Richordson) requiring rapid blood sampling. J. Fish Biol.. 18: 209-319.

Trinder, P. (1969): Ann. Clin. Biochem., 6:24. Cited from Boehringer Mannheim Gmth Diagnostica .

Wittenberger, C. and Giuvergea, R. (1973): Transaminase activities in muscle and liver of the carp. Revue Roumaine debiolopgie Serie de Zoologie., 18:441-444.

Zaghloul, K.H. (1997): Studies on the effect of water pollution along different sites of the river Nile on the survival and production of some fish water fishes. Ph. D. Thesis. Egypt.

Zulsira, N.C. (1961): Determination of hemoglobin. 106. Clin. Chem. Acta., 5:719-720.

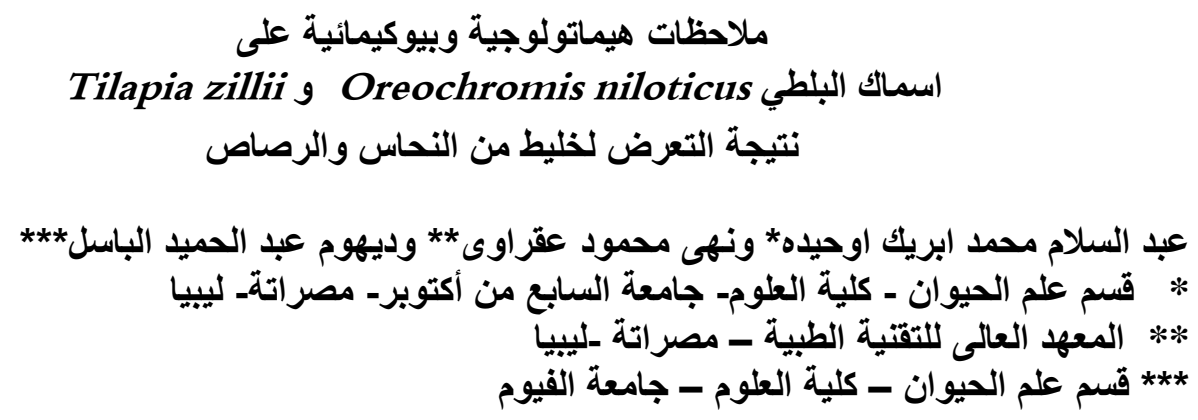

تم فى هذا البحث دراسة بعض التغير ات الهيماتولوجية والبيو كيميائية في الدم، العضلات و الكبد

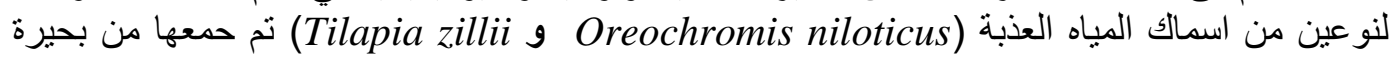

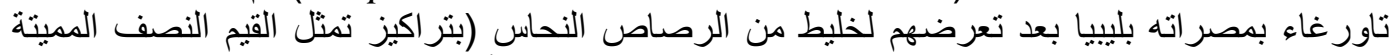

لكلا المعدنين فئ hours LC

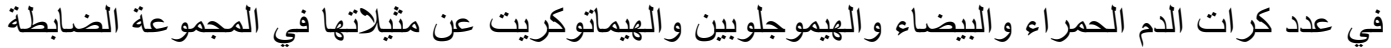

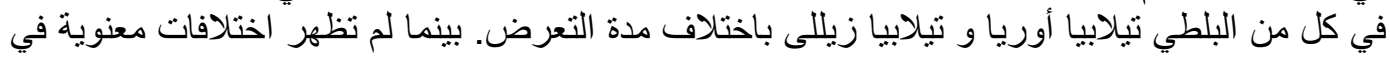

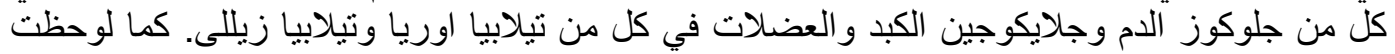

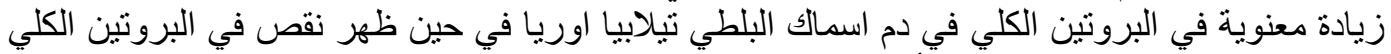

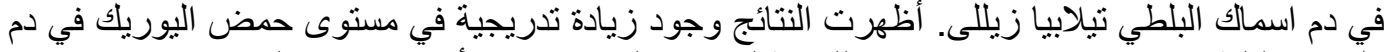

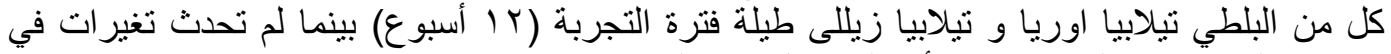

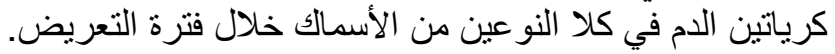

Fayoum J. Agric. Res. \& Dev., Vol.22, No.1, January, 2008 